\title{
RHEOLOGICAL BEHAVIOR OF Chlorella sp. E Scenedesmus sp. CULTURES IN DIFFERENT BIOMASS CONCENTRATIONS
}

\section{MICHEL DE O. DOS SANTOS ${ }^{1}$, MÁRCIO A. MARTINS ${ }^{2}$, JANE S. DOS R. COIMBRA ${ }^{3}$, RICHARD S. GATES ${ }^{4}$, LUCAS DE P. CORRÊDO ${ }^{5}$}

\begin{abstract}
Studies involving the use of microalgae are increasingly intensifying for the potential they present to produce biofuels, because they are a renewable energy source that does not compete directly with food production, and because they enable the obtaining of a fuel with less environmental impact when compared to fossil fuel. In this context, the use of microalgae is directly associated to its capacity to be produced on a large scale and to be extracted from the culture medium. Rheological studies are important for obtaining the information needed in the elaboration of projects and equipment that will be used in various operations existing in systems of production and extraction of algal biomass. In the evaluation of different levels of dry biomass concentration, studies have been conducted of the rheological behavior of cultures of Chlorella sp. BR001 and Scenedesmus sp. BR003. The Power Law model adjusted well to the data of shear stress as a function of strain rate. In all concentrations the cultures showed non-Newtonian behavior. It was observed to Scenedesmus sp. BR003 little effect of biomass concentration on the apparent viscosity and shear stress.
\end{abstract}

KEYWORDS: microalgae, biomass, production, operation.

\section{COMPORTAMENTO REOLÓGICO DE CULTIVOS DE Chlorella sp. E Scenedesmus sp. EM DIFERENTES CONCENTRAÇÕES DE BIOMASSA}

RESUMO: Estudos envolvendo o uso de microalgas cada vez mais se intensificam, pelo potencial que apresentam para a produção de biocombustíveis, por ser uma fonte de energia renovável que não compete diretamente com a produção de alimentos e por possibilitar a obtenção de um combustível com menor impacto ambiental quando comparado ao combustível fóssil. Neste contexto, a utilização de microalgas está diretamente associada à sua capacidade de ser produzida em larga escala e de ser extraída do meio de cultivo. Os estudos reológicos são importantes para a obtenção das informações necessárias na elaboração dos projetos e dos equipamentos que serão utilizados nas diversas operações existentes nos sistemas de produção e de extração da biomassa algal. $\mathrm{Na}$ avaliação de diferentes níveis de concentração de biomassa seca, foram realizados estudos do comportamento reológico de cultivos de Chlorella sp. BR001 e Scenedesmus sp. BR003. O modelo de Lei de Potência ajustou bem aos dados de tensão de cisalhamento em função da taxa de deformação. Em todas as concentrações, os cultivos apresentaram comportamento não newtoniano. Verificou-se para Scenedesmus sp. BR003 pouco efeito da concentração de biomassa na viscosidade aparente e na tensão de cisalhamento.

PALAVRAS-CHAVE: microalgas, biomassa, produção, operação.

\section{INTRODUCTION}

Studies involving the use of microalgae for biofuels production have attracted the attention of researchers in various parts of the world, because it enables the acquisition of a renewable fuel, of

\footnotetext{
${ }^{1}$ Engenheiro Agrícola e Ambiental, Professor Substituto, Departamento de Engenharias e Tecnologia, CEUNES/UFES, São Mateus - ES, michel.saints@gmail.com.

${ }^{2}$ Engenheiro Químico, Professor Adjunto, Departamento de Engenharia Agrícola, UFV, Viçosa - MG, aredes@ufv.br.

${ }^{3}$ Engenheira Química, Professora Associada, Departamento de Tecnologia de Alimentos, UFV, Viçosa - MG, jcoimbra@ufv.br.

${ }^{4}$ Engenheiro Agrícola, Professor, Department of Agricultural and Biological Engineering, University of Illinois at Urbana-

Champaign, Urbana - IL - EUA, rsgates@illinois.edu.

${ }^{5}$ Estudante de Engenharia Agrícola e Ambiental, Departamento de Engenharia Agrícola, UFV, Viçosa - MG, lucas.corredo@ufv.br. Recebido pelo Conselho Editorial em: 22-3-2012

Aprovado pelo Conselho Editorial em: 18-3-2013
} 
low environmental impact, which does not compete with food production. (DERMIBAS, 2011). Microalgae find applications in many other areas. They are grown to supply raw material for the sectors of aquaculture, food, cosmetics, and products with high added value, such as polyunsaturated fatty acids and pigments (GOUVEIA et al., 2007; FERREIRA et al., 2008; HARUN et al., 2010). These microorganisms are also used in treatment systems of liquid effluent in order to increase the performance of oxidized material degradation, improve the balance of $\mathrm{CO}_{2}$, reduce the demand for oxygen in the aerobic treatment systems, remove heavy metals and more resistant toxic compounds such as phenol (GAO et al., 2011).

MOLINA GRIMA et al. (2003) describe that the use of microalgae for the production of biofuels is directly related to their ability to be produced in large scale and its extraction from the culture medium. The economic viability of the insertion of biodiesel or any other byproduct from microalgae in an energy matrix depends on the reduction of costs of production and separation of the biomass. This may be achieved by increasing the productivity of biomass and oil, and optimizing the parameters from which the separation techniques are strongly dependent. In a case study on production of eicosapentaenoic acid (EPA) from the microalga $P$. tricornutum, MOLINA GRIMA et al. (2003) found that $40 \%$ of the cost is related to the production of biomass, and $60 \%$ to the processes of biomass extraction and recovery of the final product.

The rheological studies are important for obtaining data necessary for selection, sizing and design of equipment present in the various unit operations that compose the industrial processes, such as pumps, piping, mixers, aerators, extruders, homogenizers and heat exchangers, among other (STEFFE, 1996; BARNES, 2000). Thus, the design of microalgae culture systems on a large scale, as well as the sizing of the equipment used in biomass extraction techniques and other accessories, must be preceded by the investigation of the rheological properties of the culture.

The cultures of microalgae are complex suspensions, consisting of a liquid phase that contains water, dispersed or colonies algal cells, polymers derived from biological organisms and dissolved salts (WILEMAN et al., 2012). Thus, the cultivation of microalgae may present non-Newtonian behavior with pseudoplastic characteristics attributed mainly to the presence of extracellular polymeric substances (MICHELS et al., 2010; MISHRA et al., 2011). Moreover, due to the significant increase in the amount of algal biomass during the cultivation period, it is verified that there is a change in the rheological behavior, presenting an increase in viscosity and even change in the class of fluid behavior at higher biomass concentrations (WILEMAN et al., 2012).

The rheological behaviors of cultures of Chlorella sp. BR001 and Scenedesmus sp. BR003 were analyzed in different concentrations of dry biomass, with the goal of predicting changes of this behavior during the stages of production of biomass and providing data for the selection, sizing and design of equipment needed to develop a system of production of microalgal biomass.

\section{MATERIAL AND METHODS}

\section{Crops and culture conditions}

The strains of Chlorella sp. BR001 and Scenedesmus sp. BR003 microalgae belong to the strain bank of Petrobrás/UFV, which is maintained at the Laboratory of Phycology/Unit of Plant Growth (Federal University of Viçosa - UFV), located at Viçosa city, state of Minas Gerais (MG), Brazil. These strains were collected in the artificial pond of UFV, and, for the isolation, techniques of serial dilution, successive rifling on solid medium and washes with hypochlorite were used (LOURENÇO, 2007).

The cultivations were conducted in two photobioreactors of "Airlift" type which consisted of Erlenmeyer flasks of $3 \mathrm{~L}$ with an initial volume of culture medium of $2 \mathrm{~L}$, previously sterilized by autoclaving at $120^{\circ} \mathrm{C}$. The cultures were performed using the BG11 medium with nitrogen (ANDERSEN, 2005), and stirring was promoted by injection of compressed air using a compressor of $1492 \mathrm{~W}$. The air injection line had a gas cleaning system to remove oil particles and droplets from 
the compressor. The photobioreactors were installed inside a chamber with dimensions of $0.60 \mathrm{~m} \mathrm{x}$ $0.60 \mathrm{~m} \times 1.40 \mathrm{~m}$, using a light: dark photoperiod of $12: 12 \mathrm{~h}$ and light intensity of $66 \mu \mathrm{mol} \mathrm{s}{ }^{-1}$, supplied by 4 tubular fluorescent lamps of $40 \mathrm{~W}$ power each. The culture conditions were maintained for 20 days, because it was observed in previous experiments that, for these same cultivation and nutrition conditions, during this period, the growth of the biomass reaches the stationary phase. After this period, it was made the determination of biomass, density cultivation, and dilutions to reach the desired concentrations and to perform rheological tests.

\section{Determination of dry biomass and preparation of suspensions for the rheological characterization}

For the determination of dry biomass, it was removed from each photobioreactor three samples of $50 \mathrm{ml}$, where, after the collection, we proceeded to its centrifugation, at $10,000 \mathrm{~g}$ and $4^{\circ} \mathrm{C}$ for 10 minutes to separate the biomass from the culture medium. After the first centrifugation, the supernatant culture medium was removed from the tubes and the wet biomass pellet was washed with deionized water to remove the salts. The biomass suspension in water was again centrifuged at $10,000 \mathrm{~g}$ and $4^{\circ} \mathrm{C}$ for 10 minutes. The supernatant was again removed, and the wet biomass pellet was placed in Petri dishes of average weight equal to $4.2731 \mathrm{~g}$ and transferred to an oven with air circulation at $60^{\circ} \mathrm{C}$. Periodically, the biomass was measured on an analytical balance with a precision of $0.0001 \mathrm{~g}$, until it provided constant mass. The concentration of dry biomass of cultures was calculated as:

$$
X=\frac{m_{f}}{V o l}
$$

In which:

$X$ - biomass concentration in photobioreactor, $\mathrm{g} \mathrm{L}^{-1}$;

$m_{f}$ - final dry weight in oven, $\mathrm{g}$;

Vol - centrifuged sample volume, L.

The value of dry biomass was considered was equal to the average of three measurements, and suspensions used for rheological characterization were obtained by dilution of cultures, using the BG 11 medium as diluent.

\section{Rheological characterization}

The evaluation of the rheological behavior of the cultures was performed by testing with controlled strain rate and a constant temperature of $25^{\circ} \mathrm{C}$. For this, it was used a German rotational rheometer, with a measurement system of coaxial cylinders of Searle type, indicated for the apparent viscosity ranges from $5 \times 10^{-4}$ to $2 \times 10^{3} \mathrm{~Pa}$.s and able to apply strain rates in the range from 0.67 to $6,700 \mathrm{~s}^{-1}$. In measuring systems based on axial cylinders of Searle type, the inner cylinder rotates and the outer cylinder remains stationary. The test temperature was controlled by a thermostatic bath with internal and external circulation. Test data were transmitted in real time to a computer, where they could be viewed and stored. In this computer, through the software that integrates the equipment, the input of test control parameters was executed, such as temperature, strain rate to be applied, acquisition rate of data, total duration of the test, among other.

Tests were conducted to shear rates from 11 to $322 \mathrm{~s}^{-1}$, which are values representing different applications in the field of fluid mechanics of industrial interest, such as internal flow in pipes and ducts, stirring and mixture (STEFFE, 1996; BARNES, 2000). During each test, the sample was subjected to a constant strain rate, defined as a function of the speed of rotation of the inner cylinder and the geometric characteristics of the measurement system. The torque applied to the inner cylinder was measured and converted to a value of shear stress at the interface software of the instrument. In each test, we used $30 \mathrm{ml}$ of the suspensions prepared from the compacted biomass. Aiming to a better comparison of the effect of biomass concentration on the rheological behavior of the suspensions, the BG11 medium with pure nitrogen was also evaluated. All measurements were 
made with three replicates and the arithmetic averages of the results are reported (LEITE et al., 2004).

\section{Data analysis}

Data were statistically analyzed with the mathematical model of Ostwalt-de Waelle (STEFFE, 1996; BARNES, 2000), also known as the Power Law. The power law model is widely used to the rheological study of biological materials, in particular fluid systems found in food industry, such as natural and processed fruit pulp (ASTOLFI-FILHO et al., 2011), protein solutions (MANOI \& RIZVI, 2008; AROGUNDADE et al., 2011), among others. This model describes the non-linear variation of shear stress as a function of strain rate:

$$
\tau=k \gamma^{n}
$$

In which:

$$
\begin{aligned}
& \tau \text { - shear stress, } \mathrm{Pa} ; \\
& \gamma \text { - strain rate, } \mathrm{s}^{-1} ; \\
& k \text { - consistency index of the fluid, } \mathrm{Pa} \mathrm{s}^{\mathrm{n}} ; \\
& n \text { - behavior index of the fluid. }
\end{aligned}
$$

The viscosity is defined as the ratio between the shear stress and the strain rate (COSTA et al., 2005), which, in this case, is called apparent viscosity:

$$
\eta=\frac{\tau}{\gamma}=k \gamma^{n-1}
$$

In which:

$\eta$ - apparent viscosity of the fluid, Pa.s.

The analyses of variance (ANOVA) were performed and the significances of regression were tested at $1 \%$ level by $\mathrm{F}$ test.

\section{RESULTS AND DISCUSSION}

The results of the shear stress as a function of strain rate (rheograms) obtained for cultures of Chlorella sp. BR001 (concentration range of dry biomass from $0 \mathrm{~g} \mathrm{~L}^{-1}$ to $0.788 \mathrm{~g} \mathrm{~L}^{-1}$ ) and Scenedesmus sp. BR003 (concentration range of dry biomass from $0 \mathrm{~g} \mathrm{~L}^{-1}$ to $1.352 \mathrm{~g} \mathrm{~L}^{-1}$ ) are shown in Figures 1 and 2, respectively.

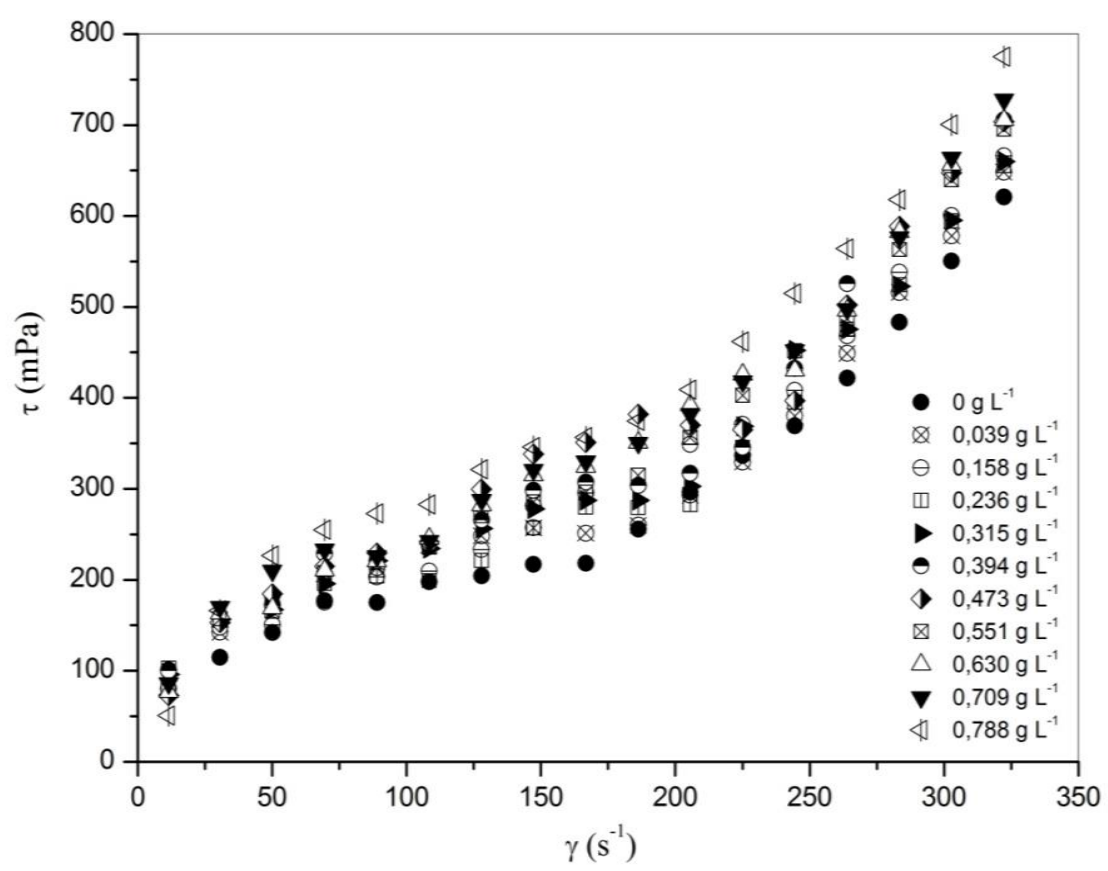

FIGURE 1. Rheogram of Chlorella sp. BR001 cultures. 


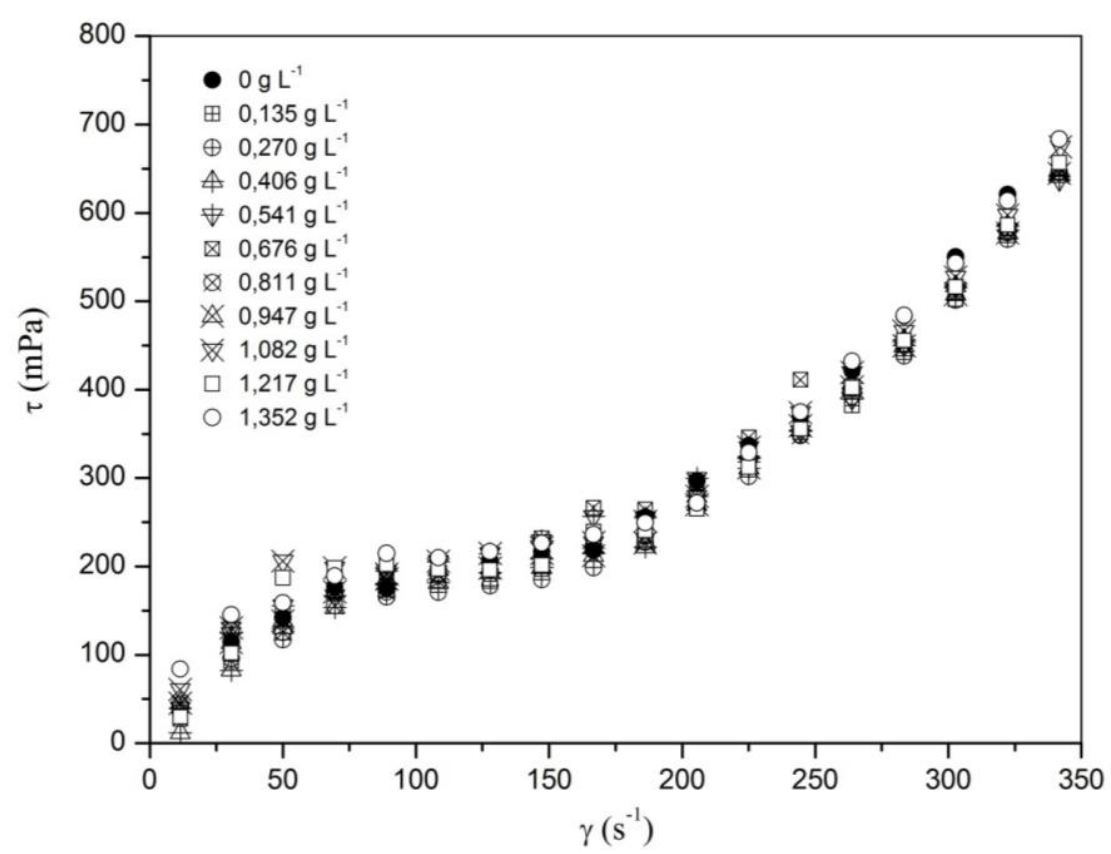

FIGURE 2. Rheogram of Scenedesmus sp. BR003 cultures.

The increase of shear stress as a function of strain rate may be seen in Figures 1 and 2. We verified that for Scenedesmus sp. BR003 there were slight differences in the values of shear stress in relation to the different biomass concentrations, while for Chlorella sp. BR001, the increase in shear stress due to high biomass concentration was more evident. The curves of apparent viscosity as a function of strain rate, obtained for the cultures of Chlorella sp. BR001 and Scenedesmus sp. BR003, in various concentrations, are shown in Figures 3 and 4, respectively.

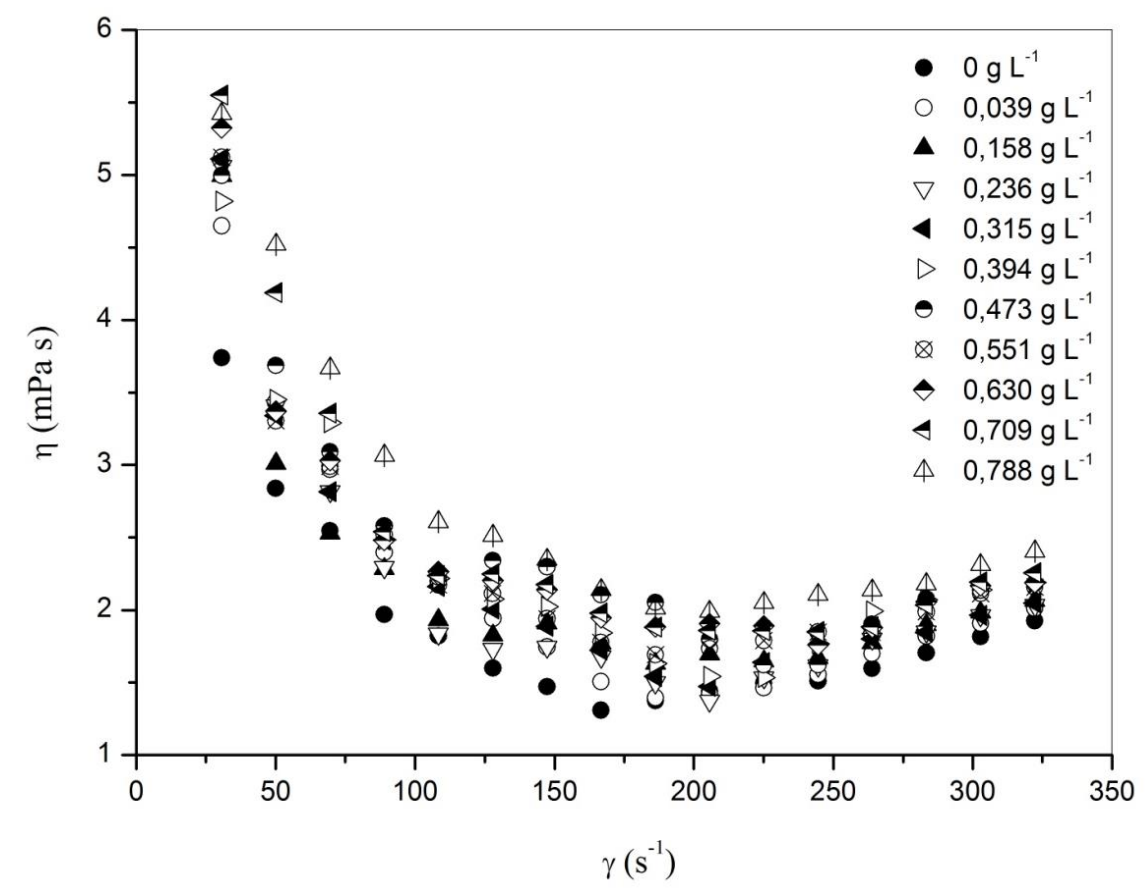

FIGURE 3. Apparent viscosity as a function of shear rate for Chlorella sp. BR001. 


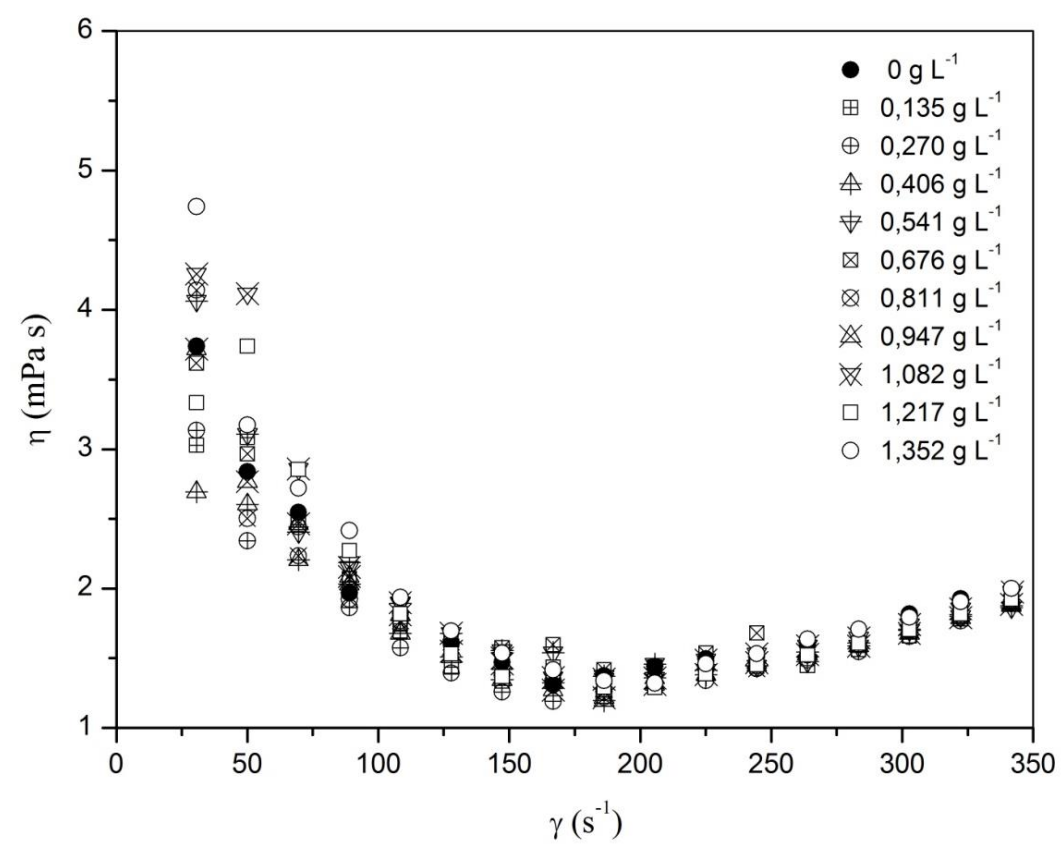

FIGURE 4. Apparent viscosity as a function of shear rate for Scenedesmus sp. BR003.

According to Barnes (2000), the increase of the viscosity of a suspension due to the increase of concentration of the dispersed phase and, consequently, the increase in shear stress, is a result of increased irreversible dissipation of mechanical energy because of the divergence of the streamlines on the flow around the particles. Regarding the culture of Scenedesmus sp. BR003 (Figure 5a), it was observed in Figure 4 little difference on the values of apparent viscosity with regard to different concentrations of dry biomass. Different from the Chlorella sp. BR001 strain (Figure 5b), the shape of this microalga may contribute to an alignment of the particles in the flow, reducing the dissipative effects of fluid mechanical energy, which may explain the small variation in rheological behavior before the increase of biomass in the studied range.

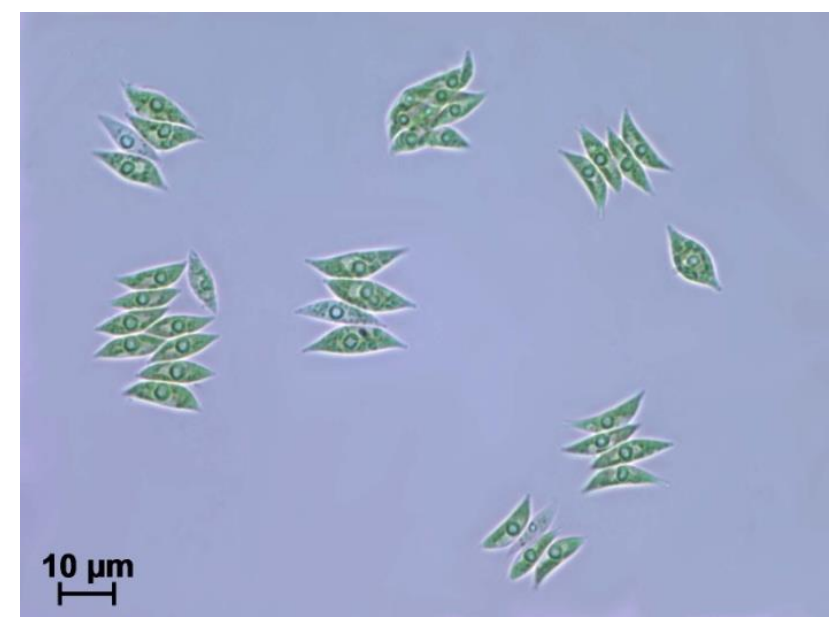

(a)

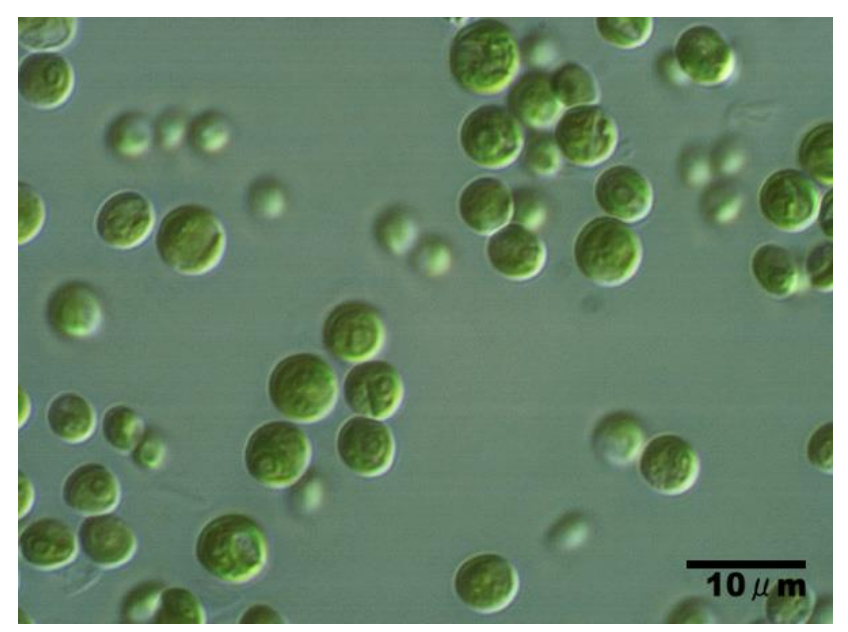

(b)

FIGURE 5. (a) Scenedesmus sp. BR003 and (b) Chlorella sp. BR001. Source: Laboratory of Phycology/UCP, UFV.

It is verified in Figure 3 that the cultures of Chlorella sp. BR001 may present apparent viscosity values of up to 6 times the water value at the same temperature $\left(0.89 \mathrm{mPa} \mathrm{s}\right.$ at $25^{\circ} \mathrm{C}$; FOX et al., 2010), while cultures of Scenedesmus sp. BR003 may present apparent viscosity values of up to 5.5 times the water viscosity value at the same temperature. The parameters of the Power Law rheological model data adjusted to the data are shown in Tables 1 and 2, along with the standard error values associated with the coefficients and the F values of the analysis of variance (ANOVA). 
TABLE 1. Parameters of Power Law model for Chlorella sp. BR001 cultures.

\begin{tabular}{ccccccc}
\hline $\begin{array}{c}\text { Concentration of dry } \\
\text { biomass }\left(\mathrm{g} \mathrm{L}^{-1}\right)\end{array}$ & $k\left(\mathrm{mPa} \mathrm{s}^{n}\right)$ & $\begin{array}{c}\text { Standard } \\
\text { error }\left(\mathrm{e}_{k}\right)\end{array}$ & $n$ & $\begin{array}{c}\text { Standard } \\
\text { error }\left(\mathrm{e}_{n}\right)\end{array}$ & $\begin{array}{c}\mathrm{R}^{2} \\
\text { adjust. }\end{array}$ & $\mathrm{F}_{\text {calculated }}{ }^{*}$ \\
\hline 0.000 & 0.697 & 0.457 & 1.163 & 0.118 & 0.910 & 403.332 \\
0.039 & 1.954 & 1.337 & 0.987 & 0.124 & 0.867 & 289.548 \\
0.158 & 1.893 & 0.981 & 1.001 & 0.094 & 0.924 & 515.215 \\
0.236 & 1.226 & 0.875 & 1.076 & 0.129 & 0.877 & 300.761 \\
0.315 & 2.518 & 1.420 & 0.950 & 0.102 & 0.900 & 403.940 \\
0.394 & 2.160 & 1.341 & 0.987 & 0.112 & 0.890 & 351.618 \\
0.473 & 4.013 & 2.001 & 0.879 & 0.090 & 0.910 & 464.348 \\
0.551 & 2.466 & 1.217 & 0.963 & 0.089 & 0.926 & 537.760 \\
0.630 & 4.601 & 1.944 & 0.851 & 0.078 & 0.931 & 606.005 \\
0.709 & 3.484 & 1.799 & 0.909 & 0.093 & 0.908 & 453.308 \\
0.788 & 5.127 & 2.101 & 0.852 & 0.074 & 0.934 & 659.172 \\
\hline
\end{tabular}

* $\mathrm{F}_{\text {tab. }(0.01 ; 2 ; 16)}=6.23$

TABLE 2. Parameters of Oswalt-De-Waelle model for Scenedesmus sp. BR003 cultures.

\begin{tabular}{ccccccc}
\hline $\begin{array}{c}\text { Concentration of dry } \\
\text { biomass }\left(\mathrm{g} \mathrm{L}^{-1}\right)\end{array}$ & $k\left(\mathrm{mPa} \mathrm{s}^{n}\right)$ & $\begin{array}{c}\text { Standard } \\
\text { error }\left(\mathrm{e}_{k}\right)\end{array}$ & $n$ & $\begin{array}{c}\text { Standard } \\
\text { error }\left(\mathrm{e}_{n}\right)\end{array}$ & $\begin{array}{c}\mathrm{R}^{2} \\
\text { adjust. }\end{array}$ & $\mathrm{F}_{\text {calculated }}$ \\
\hline 0.000 & 0.697 & 0.457 & 1.163 & 0.118 & 0.910 & 403.332 \\
0.135 & 0.850 & 0.545 & 1.115 & 0.115 & 0.913 & 392.919 \\
0.270 & 0.445 & 0.303 & 1.228 & 0.122 & 0.921 & 401.811 \\
0.406 & 0.583 & 0.353 & 1.184 & 0.109 & 0.934 & 482.192 \\
0.541 & 1.971 & 1.088 & 0.968 & 0.100 & 0.911 & 433.002 \\
0.676 & 1.645 & 0.771 & 1.005 & 0.085 & 0.942 & 633.448 \\
0.811 & 0.828 & 0.522 & 1.121 & 0.113 & 0.915 & 410.167 \\
0.947 & 0.974 & 0.638 & 1.092 & 0.118 & 0.904 & 364.894 \\
1.082 & 1.811 & 1.255 & 0.988 & 0.125 & 0.864 & 282.745 \\
1.217 & 1.345 & 0.957 & 1.036 & 0.128 & 0.876 & 287.178 \\
1.352 & 1.504 & 1.057 & 1.025 & 0.127 & 0.869 & 289.723 \\
\hline
\end{tabular}

It is observed that all the values of $F_{\text {calculated }}$ resulting of ANOVA, shown in Tables 1 and 2 are higher than the value of $\mathrm{F}$ tabulated. Thus, it can be stated that the regression equations significantly explain the variation of shear stress as a function of strain rate, according to the proposed model, at the significance level of $1 \%$. For the cultures of Chlorella sp. BR001, values of behavior index $n$ determined indicate a non-Newtonian behavior, with characteristics of pseudoplastic fluid within the range of values used for the strain rate and the concentration of dry biomass. The nonNewtonian behavior is very common in fluids containing biological material, such as pulps (VANDRESEN et al., 2009), plant extracts (LEITE et al., 2004) and thickening gums of bacterial origin (SIKORA et al., 2008). For the culture of Scenedesmus sp. BR003, in the studied concentration ranges and strain rate, values of determined behavior index $n$ indicate dilatant behavior. According to BARNES (2000), the dilatant behavior on suspensions may be attributed to the rupture of structures formed during the flow from a certain value of strain rate. However, as the values of determined $n$ are very close to the unit, under the studied conditions, the cultures of Scenedesmus sp. BR003 may also be treated as a Newtonian fluid. 


\section{CONCLUSIONS}

The Power Law model provided a proper adjustment of the experimental data. The rheological behaviors of the cultures of Chlorella sp. BR001 were non-Newtonian and with pseudoplastic characteristics, in the concentration range of dry biomass from 0 to $0.788 \mathrm{~g} \mathrm{~L}^{-1}$. The cultures of Scenedesmus sp. BR003 showed characteristics of dilatant fluid, however, the deviations of the Newtonian behavior observed were small, in the concentration range of dry biomass from 0 to $1.352 \mathrm{~g} \mathrm{~L}^{-1}$.

\section{ACKNOWLEDGEMENT}

To PETROBRÁS, for financial support to the project, and to the Support Program for the Restructuring and Expansion of Federal Universities - REUNI, for granting the scholarship.

\section{REFERENCES}

ANDERSEN, R. A. (Ed.). Algal culturing techniques. Burlington: Elsevier Academic Press, 2005. $596 \mathrm{p}$.

AROGUNDADE, L. A.; EROMOSELE, C. O.; EROMOSELE, I. C.; ADEMUYIWA, O. Rheological properties of African yam bean (Sphenostylis stenocarpa Hochst. Ex A. Rich.) calcium proteinate and isoelectric protein isolates. LWT - Food Science \& Technology, London, v.44, 524534, 2011.

ASTOLFI-FILHO, Z.; TELIS, V. R. N.; OLIVEIRA, E. B.; COIMBRA, J. S. R.; TELISROMERO, J. Rheology and fluid dynamics properties of sugar cane juice. Biochemical Engineering Journal, Amsterdam, v.53, p.260-265, 2011.

BARNES, H. A. A Handbook of elementary rheology. Aberystwyth: University of Wales, Institute of Non-Newtonian Fluid Mechanics, 2000. 200p.

COSTA, C. C.; PEREIRA, R. G.; PRATA FILHO, D. A. Influência de centrifuga no processamento do mel de abelha. Engenharia Agrícola, Jaboticabal, v.25, n.3, p.809-816, 2005.

DERMIBAS, A. Biodiesel from oilgae, biofixation of carbon dioxide by microalgae: A solution to pollution problems. Applied Energy, London, v.88, p.3541-3547, 2011.

FERREIRA, M.; MASEDA, A.; FÁBREGAS, J.; OTERO, A. Enriching rotifers with "premium" microalgae. Isochrysis aff. galbana clone T-ISO. Aquaculture, Amsterdam, v.279, p.126-130, 2008. FOX, R. W.; MCDONALD, A. T.; PRITC, P. J. Introdução à mecânica dos fluidos. 7. ed. Rio de Janeiro: Editora LTC, 2010. 728p.

GAO, Q. T.; WONG, Y. S.; TAM, N. F. Y. Removal and biodegradation of nonylphenol by immobilized Chlorella sp. Bioresource Technology, Essex, v.102, p.10230-10238, 2011.

GOUVEIA, L.; NOBRE, B. P.; MARCELO, F. M.; MJEREN, S.; CARDOSO, M. T.; PALAVRA, A. F.; MENDES, R. L. Functional food oil coloured by pigments extracted from microalgae with supercritical $\mathrm{CO}_{2}$. Food Chemistry, London, v.101, p.717-723, 2007.

HARUN, R.; SINGH, M.; FORDE, G. M.; DANQUAH, M. K. Bioprocess engineering of microalgae to produce a variety of consumer products. Renewable and Sustainable Energy Reviews, Glden, v.14, p.1037-1047, 2010.

LEITE, J. T. C.; PARK, K. J.; RAMALHO, J. R. P.; FURLAN, D. M. Caracterização Reológica das diferentes fases de extrato de inulina de raízes de chicória, obtidas por abaixamento de temperatura. Engenharia Agrícola, Jaboticabal, v.24, n. 1, p.202-210, 2004.

LOURENÇO, S. O. Cultivo de microalgas marinhas - princípios e aplicações. São Carlos: RIMA Editora, 2007. 606p. 
MANOI, K.; RIZVI, S. S. H. Rheological characterizations of texturized whey protein concentratebased powders produced by reactive supercritical fluid extrusion. Food Research International, Barking, v. 41, v.8, p.786-796, 2008.

MICHELS, M. H. A; VAN DER GOOT, A. J.; NORSKER, N. -H.; WIJFFELS, R. H. Effects of shear stress on the microalgae Chaetoceros muelleri. Bioprocess Biosystems Engineering, London, v.33, p.921-927, 2010.

MISHRA, A.; KAVITA, K.; JHA, B. Characterization of extracellular polymeric substances produced by micro-algae Dunaliella salina. Carbohydrate Polymers, Barking, v.83, p.852-857, 2011.

MOLINA GRIMA, E.; BELARBI, E. -H.; FERNÁNDEZ, A.; MEDINA, A. R.; CHISTI, Y. Recovery of microalgal biomass and metabolites: process options and economics. Biotechnology Advance, New York, v.20, n. 7-8, p.491-515, 2003.

SIROKA, M.; KOWALSKI, S.; TOMASIK, P. Binary hydrocolloids from starches and xanthan gum. Food Hydrocolloids, Oxford, v.22, n.5, p.943-952, 2008.

STEFFE, J. F. Rheological methods in food process engineering. 2nd ed. East Lansing: Freeman Press, 1996. 412p.

VANDRESEN, S.; QUADRI, M. G. N.; SOUZA, J. A. R.; HOTZA, D. Temperature effect on the rheological behavior of carrot juices. Journal of Food Engineering, Essex, v.92, p.269-274, 2009.

WILEMAN, A.; OZKAN, A.; BERBEROGLU, H. Rheological properties of algae slurries for minimizing harvesting energy requirements in biofuel production. Bioresource Technology, Essex, v.104, p.432-439, 2012. 